\title{
Thai national guidelines for antiretroviral therapy in HIV-1 infected adults and adolescents 2010
}

\author{
Somnuek Sungkanuparph ${ }^{\mathrm{a}}$, Wichai Techasathit ${ }^{\mathrm{b}}$, Chitlada Utaipiboon ${ }^{\mathrm{c}}$, Sanchai Chasombat ${ }^{\mathrm{d}}$, \\ Sorakij Bhakeecheep ${ }^{\mathrm{e}}$, Manoon Leechawengwongs ${ }^{\mathrm{f}}$, Kiat Ruxrungtham $^{\mathrm{g}, \mathrm{h}}$, Praphan Phanuphak $^{\mathrm{g}, \mathrm{h}}$, for \\ The Adults and Adolescents Committee of the Thai National HIV Guidelines Working Group \\ ${ }^{a}$ Faculty of Medicine Ramathibodi Hospital, Mahidol University, Bangkok 10400; ${ }^{b}$ Faculty of Medicine \\ Siriraj Hospital, Mahidol University, Bangkok 10700; ' Global AIDS Program, Thailand MOPH-U.S. \\ CDC Collaboration, Nonthaburi 11000; 'Bureau of AIDS, TB, and STIs, Department of Disease Control, \\ Ministry of Public Health, Nonthaburi 11000; ${ }^{e}$ National Health Security Office, Bangkok 10210; fThai \\ AIDS Society, Bangkok 10310; ${ }^{g}$ Faculty of Medicine, Chulalongkorn University, Bangkok 10330; \\ ${ }^{h} H I V-N A T$, Thai Red Cross AIDS Research Centre, Bangkok 10330, Thailand
}

In Thailand, more than 150,000 patients are currently treated with antiretroviral drugs under the support of the National AIDS Program (NAP). The appointed Adults and Adolescents Committee consisted of 28 members who are experts in HIV research, patient care or health care policy. Relevant published literature, guidelines, and the most recent relevant clinical trials presented internationally were reviewed. Several peer review and clinical studies conducted in Thailand were included in the review process. Special considerations for patients with co-infection of tuberculosis or hepatitis B were incorporated. Appropriate cut-off of CD4+ T-cell counts when to commence ART among Thai patients have been considered. It is now recommended to start ART at CD4+ T-cell count $<350$ cells $/ \mathrm{mm}^{3}$. For treatment-naive patients, the preferred initial therapy is a nonnucleoside reverse transcriptase inhibitor (NNRTI)-based regimen containing lamivudine plus zidovudine or tenofovir. Stavudine will be phased out in a two-year plan at the national program level. Viral load and CD4+ T-cell counts should be monitored at least once and twice a year. To achieve long-term treatment success, enhancing adherence together with the proper management of antiretroviral-related toxicity is critical. In summary, the major changes from the Thai 2008 guidelines include commencing ART earlier. ART is recommended regardless of CD4+ T cell count if patients have an indication to treat their HBV co-infection. Preferred first regimen uses AZT or TDF, not d4T as the NRTI-backbone. Furthermore, efavirenz is now considered a preferred NNRTI, along with nevirapine.

Keywords: Adolescent, adult, antiretroviral, HIV, Thai guidelines

HIV-1 antiretroviral therapy (ART) has evolved and improved significantly since the advent of combined ART. Optimal management of ART has resulted in substantial reductions in morbidity, mortality, and health care utilization $[1,2]$. Benefits from ART have been proven in resource-limited settings including Thailand [3-6] where generic antiretroviral drugs are

Correspondence to: Assist Prof. Wichai Techasathit, Department of Preventive and Social Medicine, Faculty of Medicine Siriraj Hospital, Mahidol University, Bangkok 10700, Thailand. E-mail:srwtc@mahidol.ac.th available at a much lower cost $[7,8]$. However, there is no ideal ART regimen. Different regimens may have efficacy profiles, adverse effects, and/or drug-drug interactions, thus it can be difficult for non-specialized physicians to manage patients on ART. These problems continue to limit the effectiveness of ART in resource-limited settings [9]. Currently, more than 150,000 patients are treated with ART under the National AIDS Program (NAP) in Thailand. The Thai AIDS Society (TAS) previously launched recommendations in 2008 for the use of ART in HIV-1 infected adults and adolescents [10]. Significant 
changes including recommended antiretroviral regimens and optimal time of initiation have been addressed based on recent literature, as reflected in the new international guidelines $[11,12]$.

A number of recommendations of those updated international guidelines are not implementable in developing countries such as Thailand. The Ministry of Public Health (MOPH), the National Social Health Office (NHSO), and the Thai AIDS Society (TAS) therefore appointed The Thai National HIV Guidelines Working Group (TNHIVWG) to update Thai Guidelines based on their expertise in HIV clinical research, patient care, patient insight, and government policy in Thailand. The Adults and Adolescents Committee consists of 28 members. Relevant published literature and guidelines as well the most recent relevant clinical trials presented internationally were reviewed. Several peer reviewed published clinical studies conducted in Thailand were included in the reviewing process. The recommendations were based on the strength of evidence and the availability of antiretroviral agents through the NAP. Published studies, that are relevant and applicable to Thailand in particular, have been taken into consideration. The new guidelines were drafted by the committee and reviewed by the (TNHIVWG). These Guidelines focuses on practical key recommendations, i.e. when to initiate ART in adults and adolescents with HIV-1 infection; which regimens are preferred initial treatment; how to monitor the treatment response; what are common adverse effects; how to diagnose treatment failure; what are the concepts of selecting ART in patients with treatment failure; and selected special considerations in specific patients.

\section{Antiretroviral therapy for treatment-naive HIV- 1 infected adults and adolescents \\ Patient evaluation and preparation prior to initiating antiretroviral therapy}

Histories of current and prior antiretroviral agents (ARVs) including zidovudine (AZT) and single dose nevirapine (NVP), particularly during pregnancy, should be reviewed. Selection of the optimal regimen for HIV-1 infected individuals is based on assessment of efficacy, accessibility, related adverse effects, underlying diseases (e.g. diabetes, hypertension), coinfections (TB, HBV), and the potential for drug-drug interactions. Proper patient counseling is essential for life-long therapy and long-term and durability of the treatment success. This includes adherence, the potential risk of adverse drug effects or immune reconstitution inflammatory syndrome (IRIS) following ART; particularly in patients with advanced clinical stage or CD4+ T-cell $<100$ cells $/ \mathrm{mm}^{3}[13,14]$ and long-term ARV-related complications. Baseline evaluation should include complete blood count, CD4+ T-cell count, plasma HIV-1 RNA (if available), fasting blood glucose, serum lipid profile (total cholesterol, LDL, HDL), AST, ALT, serum creatinine, HBsAg, VDRL, urinalysis, chest X-ray, and PAP smear (in women). Anti-HCV antibody should be tested in patients with a history of intravenous drug use [15, 16]. In patients with CD4+ T-cell count $<50$ cells $/ \mathrm{mm}^{3}$, a fundoscopic examination to identify cytomegalovirus (CMV) retinitis is recommended.

\section{Initiation of antiretroviral therapy}

The ultimate goal of ART is to achieve maximal and durable plasma HIV-1 viral load (VL) suppression to an undetectable level of $<50$ copies $/ \mathrm{mL}$. Long-term durability of viral suppression has been documented in various settings of resource levels including Thailand [5, 17-22]. A cohort of up to 4000 patients from Denmark has shown that for a young person diagnosed with HIV infection in the late ART era, the estimated median survival is more than 35 years [23]. This information is important to motivate our patients for their long-term commitment in treatment adherence.

\section{When to start antiretroviral therapy}

A recommendation of when to start ART is fundamentally based on patient's symptoms [24, 25] and CD4+ T-cell counts, as shown in Table 1. The appropriate cut-off of CD4+ T cell count for when to start ART among Thai patients has been reconsidered. Recent cohort studies provide evidence supporting the benefit of ART in reducing AIDS- and non-AIDS associated morbidity and mortality in patients with CD4+ T cell counts of less than 350 cells $/ \mathrm{mm}^{3}$ [26-29]. Moreover, the only recent randomized trial that was conducted in Haiti known as "CIPRA HT 001" provides strong support to initiate ART before the CD4 count falls below 350 cells $/ \mathrm{mm}^{3}$ [30]. The earlier ART is initiated, the sooner the patients will achieve adequate immune status to prevent morbidity and mortality from opportunistic infections. This has also been demonstrated in a Thai setting [31]. In addition, accessibility to ART has been supported in Thailand. Thus, it is recommended that adults or adolescents with HIV-related symptoms or AIDS or with a CD4+ T-cell count $<350$ cells $/ \mathrm{mm}^{3}$ should initiate treatment with ART. 
Table 1. Indications for initiation of antiretroviral therapy (ART).

\begin{tabular}{ccc}
\hline Clinical Presentation & $\begin{array}{c}\text { CD4+ T-cell } \\
\text { counts } \\
\left(\mathbf{c e l l s} / \mathbf{m m}^{3}\right)\end{array}$ & Recommendations \\
\hline AIDS-defining illness* & Any value & Treat \\
HIV-related Symptomatic** & $\begin{array}{c}\text { Any value } \\
\text { Asymptomatic }\end{array}$ & $\begin{array}{c}\text { Treat } \\
\text { Treat }\end{array}$ \\
Asymptomatic & $\geq 350$ & Defer treatment; follow up clinical status and monitor \\
Pregnancy & Any value & Treat, Discontinue ART after delivery if pre-treatment \\
& & CD4+ T-cell count is $\geq 350$ cells $/ \mathrm{mm}^{3}$
\end{tabular}

*as described in the 1993 revised classification system for HIV infection and expanded surveillance case definition for AIDS among adolescents and adults [24] and with penicilliosis, which is considered as AIDS-defining illness in Thailand [25]. **oral candidiasis, pruritic papular eruptions (PPE), unexplained fever or diarrhea $>$ two weeks, $>10 \%$ unexplained weight loss in 3 months, or herpes zoster involved $>$ two dermatomes.

\section{Special considerations}

\section{Pregnant women with HIV infection}

ART is recommended for pregnant women with HIV-1 infection at any CD4+ T cell count. ART should be discontinued after delivery for those in whom the pre-treatment CD4+ T-cell count was $\geq 350$ cells $/ \mathrm{mm}^{3}$.

Other special settings with CD4+ T cell counts $>350$ cells $/ \mathrm{mm}^{3}$

The panel recommends considering initiating ART in the following special settings regardless of a patient's $\mathrm{CD} 4+\mathrm{T}$ cell count level: $\mathrm{HBV}$ or $\mathrm{HCV}$ co-infection when treatment for $\mathrm{HBV}$ or $\mathrm{HCV}$ and in patients older than 50 years with co-morbid diseases. To avoid over-prescribing of ARVs, expert consultation is recommended for those who are discordant couples, and in those with HIV-associated nephropathy.

\section{Preferred initial antiretroviral regimen (Table 2)}

Non-nucleoside reverse transcriptase inhibitor (NNRTI)-based regimens are recommended as preferred first-line treatment. The efficacy of generic fixed-dose combination (FDC) NVP-based regimens has been well demonstrated [7-9, 32]. Together with its affordable cost and simplicity, it is recommended as preferred first regimen. An efavirenz (EFV)based regimen that can be given once-daily is also recommended as another preferred first regimen. $\mathrm{EFV}$ is not recommended for use in the first trimester of pregnancy or in sexually active women with childbearing potential who are not using effective contraception. In patients who cannot tolerate NVP and/or EFV, ritonavir-boosted lopinavir (LPV/r) is a recommended alternative. To achieve good adherence, patients should be advised to take the correct dosage of ARVs, to avoid missing any doses and to take the medications at the same time every day (i.e., every 12 hours for twice-daily regimens or every 24 hours for a once-daily regimen). Indinavir is no longer recommended due to its high rate of renal stones and toxicities.

For NRTI, zidovudine (AZT) or tenofovir (TDF) in combination with lamivudine (3TC) is recommended as the preferred backbone. Stavudine (d4T) is no longer recommended as first-line drug due to its high rate of toxicities. The Thai NAP has positioned a twoyear phase out policy for patients who have been taking d4T [33, 34]. Patients who have d4T-related lipoatrophy should switch to TDF, while their VL is undetectable. Those who have no $\mathrm{d} 4 \mathrm{~T}$ toxicity may switch to AZT.

In HIV-1/HBV co-infected patients, tenofovir (TDF) + 3TC or emtricitabine (FTC) is recommended. Abacavir $(\mathrm{ABC})+3 \mathrm{TC}$ and didanosine $(\mathrm{ddI})+3 \mathrm{TC}$ are considered as alternatives NRTI-backbones for patients who cannot tolerate the preferred NRTI combinations. TDF is recommended in patients who cannot tolerate AZT, or have progression of lipodystrophy. Currently available ARVs in Thailand and the recommended dosages are summarized in Table 3. 
Table 2. Recommended preferred and alternative first ART regimens.

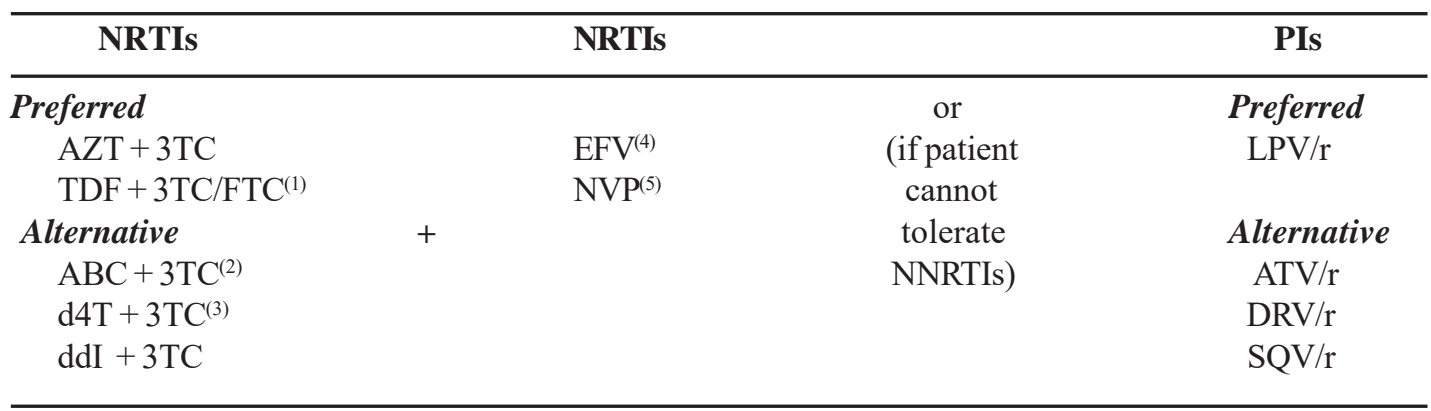

All ARVs in the above table are listed in alphabetical order. ${ }^{(1)} \mathrm{TDF}$ should be used in caution in patients with abnormal creatinine clearance and in elderly patients. TDF $+3 \mathrm{TC} / \mathrm{FTC}$ is recommended in patients with HBV co-infection [2]. ${ }^{(2)} \mathrm{ABC}$ can cause hypersensitivity reactions and should not be used with NVP. ${ }^{(3)} \mathrm{d} 4 \mathrm{~T}$, if used, should be replaced with another NRTI after 6-12 months. ${ }^{(4)}$ It cannot be used in the first trimester of pregnancy. ${ }^{(5)} \mathrm{NVP}$ should be used with caution in females with CD4+ T cell counts $>250$ cells $/ \mathrm{mm}^{3}$.

Table 3. Currently available ARVs in Thailand and recommended dosages.

\begin{tabular}{|c|c|c|c|}
\hline Classes & Drugs & Preparations & Dosages \\
\hline \multirow{7}{*}{$\begin{array}{l}\text { Nucleoside reverse } \\
\text { transcriptase } \\
\text { inhibitors (NRTIs) }\end{array}$} & abacavir (ABC) & $300 \mathrm{mg}$ & $\begin{array}{l}300 \mathrm{mg} \text { every } 12 \text { hours, or } \\
600 \mathrm{mg} \text { every } 24 \text { hours }\end{array}$ \\
\hline & didanosine (ddI) & $\begin{array}{l}\text { chewable buffered } \\
\text { tablets }(125,200 \mathrm{mg}) \text {, } \\
\text { enteric coated } \\
\text { capsule }(250,400 \mathrm{mg})\end{array}$ & $\begin{array}{l}250 \mathrm{mg} 1 \text { hour before meal every } 24 \text { hours } \\
\text { for weight }<60 \mathrm{Kg} \text {., or } \\
400 \mathrm{mg} 1 \text { hour before meal every } 24 \text { hours } \\
\text { for weight } \geq 60 \mathrm{Kg} \text {. }\end{array}$ \\
\hline & lamivudine (3TC) & $150,300 \mathrm{mg}$ & $\begin{array}{l}300 \mathrm{mg} \text { every } 24 \text { hours, or } \\
150 \mathrm{mg} \text { every } 12 \text { hours }\end{array}$ \\
\hline & stavudine $(\mathrm{d} 4 \mathrm{~T})$ & $30 \mathrm{mg}$ & 30 mg every 12 hours \\
\hline & tenofovir (TDF) & $300 \mathrm{mg}$ & $300 \mathrm{mg}$ every 24 hours \\
\hline & $\begin{array}{l}\text { TDF/emtricitabine } \\
\text { (FTC) }\end{array}$ & $300 / 200 \mathrm{mg}$ & one tablet every 24 hours \\
\hline & zidovudine (AZT) & $100,250,300 \mathrm{mg}$ & 200-300 mg every 12 hours \\
\hline \multirow{4}{*}{$\begin{array}{l}\text { Non-nucleoside } \\
\text { reverse } \\
\text { transcriptase } \\
\text { inhibitors } \\
\text { (NNRTIs) }\end{array}$} & efavirenz (EFV) & $200,600 \mathrm{mg}$ & $600 \mathrm{mg}$ every 24 hours before bedtime \\
\hline & etravirine (ETR) & $100 \mathrm{mg}$ & $200 \mathrm{mg}$ every 12 hours \\
\hline & nevirapine (NVP) & $200 \mathrm{mg}$ & 200 mg every 12 hours \\
\hline & & & \\
\hline \multirow[t]{5}{*}{$\begin{array}{l}\text { Protease } \\
\text { inhibitors (PIs) }\end{array}$} & atazanavir (ATV) & $300 \mathrm{mg}$ & $\begin{array}{l}300 \mathrm{mg}+\mathrm{RTV} 100 \mathrm{mg} \text { every } 24 \text { hours } \\
\text { with food* }\end{array}$ \\
\hline & darunavir (DRV) & $300 \mathrm{mg}, 400 \mathrm{mg}$ & $\begin{array}{l}600 \mathrm{mg}+\text { RTV } 100 \mathrm{mg} \text { every } 12 \text { hours } \\
\text { with food, or } \\
800 \mathrm{mg}+\mathrm{RTV} 100 \mathrm{mg} \text { every } 24 \text { hours } \\
\text { with food** }\end{array}$ \\
\hline & $\begin{array}{l}\text { lopinavir/ritonavir } \\
(\mathrm{LPV} / \mathrm{r})\end{array}$ & $100 / 25,200 / 50 \mathrm{mg}$ & $\begin{array}{l}400 / 100 \mathrm{mg} \text { every } 12 \text { hours with food, or } \\
800 / 200 \mathrm{mg} \text { every } 24 \text { hours with food** }\end{array}$ \\
\hline & ritonavir (RTV) & $100 \mathrm{mg}$ & Only used as PI booster in the regimen \\
\hline & saquinavir (SQV) & $500 \mathrm{mg}$ & $\begin{array}{l}1000 \mathrm{mg}+\text { RTV } 100 \mathrm{mg} \text { every } 12 \text { hours } \\
\text { with food, or } \\
1500 \mathrm{mg}+\text { RTV } 100 \mathrm{mg} \text { every } 24 \text { hours } \\
\text { with food** }\end{array}$ \\
\hline Integrase inhibitors & raltegravir (RAL) & $400 \mathrm{mg}$ & $400 \mathrm{mg}$ every 12 hours \\
\hline
\end{tabular}

\footnotetext{
*when used with TDF or EFV, use with RTV only; avoid taking with antacids, H2-blocker or proton pump inhibitors.
}

**once daily dosing is recommended for ARV-na ve patients only. 


\section{Treatment-naive HIV-1 patients with opportunistic infections (OIs)}

Although these new guidelines recommend starting treatment earlier, in reality, a significant number of patients are clinically advanced when first seeking medical care. Starting ART in patients with advanced HIV disease, low CD4+ T-cell count with or without active opportunistic infections (OIs) puts patients at risk for drug-related toxicity, or immune reconstitution inflammatory syndrome (paradoxical IRIS). Appropriate timing to initiate ART in patients with active OIs is not yet well established. In the setting of cryptosporidiosis, microsporidiosis, progressive multifocal leukoencephalopathy (PML), and Kaposi sarcoma, the benefits of early ART outweigh any increased risk, and a recommended ART regimen should be started as soon as possible. In cases of Mycobacterium avium complex (MAC), PCP, cryptococcal meningitis, and $\mathrm{CMV}$ retinitis, we recommend to defer ART initiation following the OI therapy by approximately two to four weeks. In patients who have an OI occurring within or after 12 weeks of starting ART (unmasking IRIS), treatment for the OI should be started while continuing ART.

\section{Antiretroviral therapy in treatment-naive HIV-1 / TB co-infection}

Tuberculosis (TB) is the most common reactivated infectious disease in HIV-1 infected patients. A rifampicin-based anti-TB regimen is essential. Nonetheless, rifampicin induces hepatic cytochrome P-450 resulting in a significant decrease of plasma NNRTI and protease inhibitor (PI) levels $[35,36]$. In addition, ARVs and anti-TB medications have overlapping toxicities, particularly cutaneous and hepatic adverse events. Drug-drug interactions and additive toxicity complicate treatment of this coinfection. The importance of treatment adherence to both ART and anti-TB regimens for a successful treatment outcome must be convincingly emphasized to patients. Liver and kidney function should be tested prior to the initiation of ART.

A recent study has demonstrated that initiation of ART during tuberculosis therapy significantly improved survival compared to when ART was initiated after the completion of TB treatment [37]. However, the optimal timing for initiating ART during TB treatment remains unknown. Simultaneous initiation of both ART and therapy for TB should be avoided due to the increased risks of IRIS and additive toxicity. The panel recommends deferring ART until anti-TB treatment has been started for at least four to eight weeks [38-40].

Indications for when to initiate ART in HIV-1/TB co-infection are summarized in Table 4. Patients who are treated with non-rifampicin containing anti-TB regimens, the ART guidelines are applicable same as for non-TB patients. For patients who are treated with rifampicin-containing anti-TB regimen, EFV-based ART is recommended. The dosage of EFV is $600 \mathrm{mg} /$ day for weight $<60 \mathrm{~kg}$ and $800 \mathrm{mg} /$ day for weight $\geq 60$ $\mathrm{kg}$ [32]. A number of studies in Thailand have shown that NVP at a normal dose of $400 \mathrm{mg}$ /day can be used effectively with rifampicin [36, 40, 41]. One study found that an increase of NVP dose to $600 \mathrm{mg}$ per day, with a lead-in of $200 \mathrm{mg}$ twice daily, was associated with a high rate of hepatotoxicity and is therefore not recommended. Thus, a standard dose of NVP is an alternative to EFV for patients treated with rifampicin, and lead-in NVP treatment $(200 \mathrm{mg} /$ day) for the first 14 days may be not necessary [36, 42]. If the patient cannot tolerate EFV- or NVPcontaining ART and cannot wait until the completion of TB treatment (e.g. CD4+ T-cell count $<100$ cells/ $\mathrm{mm}^{3}$ ), one should consider using a non-rifampicin containing anti-TB regimen PI-containing ART. It may not be necessary to switch NVP to EFV in patients who have been on NVP and must be treated with rifampicin, but they need monitoring.

Table 4. Indications for initiation of ART in patients with HIV and tuberculosis (TB) co-infection.

\begin{tabular}{cl}
\hline $\begin{array}{l}\text { CD4+ T cell counts } \\
\left(\text { cells } / \mathbf{m m}^{3}\right)\end{array}$ & Recommendations \\
\hline$<200$ & Start ART 2-8 weeks after the initiation of TB treatment \\
$200-<350$ & Start ART 2 months after the initiation of TB treatment \\
$\geq 350$ & Defer ART Follow up clinical status and monitor CD4+ T-cell count every 6 months
\end{tabular}




\section{Monitoring antiretroviral therapy}

Clinical review and relevant laboratory and adherence monitoring are crucial to detect early treatment failure or drug-related adverse effects. Table 5 summarizes the recommended laboratory monitoring. The best laboratory tools to evaluate treatment response are plasma HIV-1 VL and CD4+ T-cell count. VL is more accurate and reliable than CD4+ T-cell count to monitor treatment response and for early detect treatment failure [12, 43]. Effective ART regimens and high level of adherence result in suppression of VL to $<50$ copies/mL by six months of ART [44]. A detectable VL after six months of ART or a rebound in VL after achieving an undetectable level should prompt evaluation of the patient's adherence and any other causes of treatment failure. In treatment failure, a rebound of VL precedes the decline of CD4+ T-cell counts by several months.

It is recommended to monitor VL regularly for at least every six months in the first year of ART and at least yearly later on. Patients with poor adherence should be advised to take the medications well, and then have a reassessment of plasma VL in a few weeks to identify treatment failure. CD4+ T-cell count monitoring is important to evaluate immune restoration after ART and to determine when to stop OI prophylaxes. CD4+ T cell count should be performed every six months.

In general, CD4+ T cell counts usually increase by approximately $50-150$ cells $/ \mathrm{mm}^{3}$ per year of ART [45], until reaching the normal levels. However, some patients may experience a slower increase of CD4+ T cell counts particularly when ART were initiated at very low CD4 count levels. Recent studies have demonstrated that CD4+ T cell criteria, either at $25 \%$ or $50 \%$ declining from baseline levels, are not accurate for determining treatment failure [46-48]. More importantly, when using CD4+ T cell criteria alone, misclassification of treatment failure among patients with a CD4 count that has declined, but with undetectable plasma VL are common [48]. For this reason, monitoring $\mathrm{CD} 4+\mathrm{T}$ cell count alone is not recommended.

Table 5. Recommended laboratory monitoring after initiation of ART.

\begin{tabular}{|c|c|c|c|}
\hline \multirow[t]{2}{*}{ Laboratory tests } & \multicolumn{2}{|c|}{ Recommended time for the test } & \multirow[t]{2}{*}{ Note } \\
\hline & First year of ART & Following years & \\
\hline CBC, CD4+ T-cell count & at 6 and 12 months & every 6 months & \\
\hline Plasma VL & $\begin{array}{l}\text { First regimen: } \\
\text { at } 6 \text { and } 12 \text { months } \\
\text { The next regimens: } \\
\text { at } 3 \text { and } 6 \text { months }\end{array}$ & $\begin{array}{l}\text { every } 12 \text { months (every } \\
6 \text { months is preferred) } \\
\text { every } 12 \text { months }\end{array}$ & $\begin{array}{l}\text { should be performed before } \\
\text { switching of ARVs due to } \\
\text { adverse effects }\end{array}$ \\
\hline FBS & at 6 and 12 months & every 6 months & \\
\hline ALT & at 6 and 12 months & every 6 months & $\begin{array}{l}\text { should be performed at } 3 \\
\text { months if NNRTI is used }\end{array}$ \\
\hline Creatinine* & at 6 and 12 months & every 6 months & $\begin{array}{l}\text { strongly recommended if } \\
\text { TDF is used }\end{array}$ \\
\hline $\begin{array}{l}\text { Lipid profile (TC, TG, } \\
\text { LDL,HDL) }\end{array}$ & at 6 and 12 months & every 6 months & \\
\hline Urinalysis & - & - & $\begin{array}{l}\text { should be performed every } \\
12 \text { months if TDF is used }\end{array}$ \\
\hline CXR & - & - & $\begin{array}{l}\text { perform when clinical status } \\
\text { indicates }\end{array}$ \\
\hline Pap smear & at 12 months & every 12 months & $\begin{array}{l}\text { perform when clinical status } \\
\text { indicates }\end{array}$ \\
\hline
\end{tabular}

*for calculation of creatinine clearance. 
Adverse effects of ARVs and their management

Treatment of HIV-1 infection with ART represents a complicated balance between the benefits of maximal durable viral suppression and the risks of adverse drug effects. ARV-related adverse effects occur across a broad spectrum. The most common reason for switching or discontinuing ART is adverse effect [49]. Adverse effects may occur early or late following ART initiation. Some of these effects can affect a patient's quality of life and the medication adherence. Common adverse effects from ARVs are summarized in Table 6. ARV that causes adverse effects should be replaced with other ARV in the same class but does not have overlapping adverse effects. To minimize the risk of subsequent HIV drug resistance to NNRTIs, the NRTI backbone should be continued for seven to 10 days if NNRTI in the same regimen is discontinued due to adverse effect [50]. In case of severe adverse effects, e.g. lactic acidosis, or StevensJohnson syndrome, all ARVs should be stopped immediately. Lipodystrophy is one of the most common long-term adverse effect of d4T, some boosted PIs and EFV in particular [33, 34, 51]. Early switching of the causative ARV may avoid irreversible lipodystrophy. Dyslipidemia is common among patients taking PIs, EFV, and d4T [52-54]. Monitoring and management of this metabolic complication, as well as other conventional risks, can minimize the risk of cardiovascular diseases.

\section{Immune reconstitution inflammatory syndrome (IRIS)}

IRIS is a syndrome that usually occurs in patients with immune restoration after the initiation of ART at low $\mathrm{CD} 4+\mathrm{T}$ cell counts. IRIS can be categorized into two major clinical patterns: 1) Paradoxical IRIS occurs in a clinical setting when a completely or partially treated OI recurs or worsens following ART initiation; and 2) Unmasking IRIS is defined as a clinical activation of an unregconized and previously untreated OI. It should be noted that IRIS could also occur as a non-infectious inflammatory disease. In Thailand,

Table 6. Adverse effects of ARVs.

\begin{tabular}{|c|c|c|}
\hline Classes & Drugs & Adverse effects \\
\hline \multirow[t]{7}{*}{$\begin{array}{l}\text { Nucleoside reverse } \\
\text { transcriptase } \\
\text { inhibitors (NRTIs) }\end{array}$} & $\begin{array}{l}\text { abacavir }(\mathrm{ABC}) \\
\text { didanosine }(\mathrm{ddI})\end{array}$ & $\begin{array}{l}\text { hypersensitivity reactions } \\
\text { peripheral neuropathy, pancreatitis, nausea, vomiting, hepatitis, } \\
\text { hyperlactatemia, lactic acidosis }\end{array}$ \\
\hline & lamivudine (3TC) & nausea, vomiting (very rare) \\
\hline & stavudine $(\mathrm{d} 4 \mathrm{~T})$ & $\begin{array}{l}\text { peripheral neuropathy, lipoatrophy, dyslipidemia, } \\
\text { hyperlactatemia and lactic acidosis }\end{array}$ \\
\hline & tenofovir (TDF) & renal toxicity, Fanconi syndrome, nephrogenic diabetic insipidus \\
\hline & emtricitabine (FTC) & nausea, vomiting, diarrhea, abdominal distension, weakness \\
\hline & zidovudine (AZT) & nausea, vomiting, headache, insomnia, asthenia, bone marrow \\
\hline & & suppression (macrocytic anemia, neutropenia), nail hyperpigmentation \\
\hline Non-nucleoside & efavirenz (EFV) & rash, central nervous system symptoms (dizziness, somnolence, \\
\hline $\begin{array}{l}\text { reverse } \\
\text { transcriptase }\end{array}$ & & $\begin{array}{l}\text { insomnia, abnormal dreams, confusion), dyslipidemia, increased } \\
\text { transaminases, teratogenicity }\end{array}$ \\
\hline inhibitors & etravirine (ETR) & rash, nausea, vomiting, abdominal pain \\
\hline (NNRTIs) & nevirapine (NVP) & $\begin{array}{l}\text { rash, Stevens-Johnson syndrome, toxic epidermal necrolysis, } \\
\text { hepatotoxicity }\end{array}$ \\
\hline \multirow[t]{6}{*}{$\begin{array}{l}\text { Protease } \\
\text { inhibitors (PIs) }\end{array}$} & atazanavir (ATV) & $\begin{array}{l}\text { indirect hyperbilirubinemia, prolonged PR interval, first degree } \\
\text { AV block (uncommon) }\end{array}$ \\
\hline & darunavir (DRV) & nausea, vomiting, dyslipidemia, \\
\hline & lopinavir/ritonavir & nausea, vomiting, diarrhea, dyslipidemia especially \\
\hline & (LPV/r) & hypertriglyceridemia, lipodystrophy \\
\hline & ritonavir(RTV) & $\begin{array}{l}\text { nausea, vomiting, diarrhea, dyslipidemia especially } \\
\text { hypertriglyceridemia, lipodystrophy }\end{array}$ \\
\hline & saquinavir (SQV) & $\begin{array}{l}\text { nausea, vomiting, diarrhea, headache, dyslipidemia, increased } \\
\text { transaminases, lipodystrophy }\end{array}$ \\
\hline Integrase inhibitors & raltegravir (RAL) & diarrhea, headache, nausea \\
\hline
\end{tabular}


the majority of IRIS is caused by Mycobacterium tuberculosis, MAC, and Cryptococcus neoformans [13, 14, 55-57]. The clinical manifestations of IRIS usually appear within the first three months following ART initiation. Patients with baseline CD4+ T-cell counts and fewer than 50 cells $/ \mathrm{mm}^{3}$ have a high risk of IRIS [58]. Due to the non-specific clinical manifestations, physicians must be vigilant to diagnose IRIS. However, as part of the differential diagnosis, other causes such as adverse effects of ART or treatment failure with deterioration of HIV status must be excluded. Most patients with IRIS recover within two to four weeks and do not need to interrupt ART. Treatment of OI should be administered as indicated. Non-steroid anti-inflammatory drugs or systemic corticosteroids may be given according to the severity of inflammation [59].

\section{Antiretroviral treatment failure Diagnosis of treatment failure}

Treatment failure is generally associated with virological failure, immunologic failure, and/or clinical progression. Nonetheless, virological failure is the most sensitive measure of early treatment failure. Early diagnosis can prevent the accumulation of drugresistant associated mutations (RAMs) and preserve antiretroviral options. Therefore, the panel therefore primarily recommends using virological failure to define treatment failure. The Thai national program provides free plasma VL tests two times in the first year, then once a year. Furthermore, it recommends monitoring patients who are taking ART. The criteria for treatment failure are plasma VL $>400$ copies $/ \mathrm{mL}$ after six months of ART with good adherence, or plasma VL $>50$ copies/mL after 12 months of ART with good adherence, or a rebound of plasma VL to $>50$ copies $/ \mathrm{mL}$ occurring at any time after achieving $\mathrm{VL}<50$ copies $/ \mathrm{mL}$. Patients who have a plasma VL of 51-1000 copies/mL may be in a very early stage of treatment failure or may be experiencing a transient viremia (viral blip, which is not associated with treatment failure). These patients should be counseled on the importance of adherence to ART and their plasma VL should be reassessed within two to three months. Although treatment failure is suggested when plasma VL is $>50$ copies $/ \mathrm{mL}$, HIV-1 drug resistance genotype tests can only be successfully analyzed when plasma VL is $>1000$ copies $/ \mathrm{mL}$. Based on costeffectiveness considerations, the panel recommends HIV-1 drug resistance genotype testing when the plasma VL $>2000$ copies $/ \mathrm{mL}$. It is important that the drug resistance genotype test should be performed while patients are still taking the ART. Discontinuation of ART prior to the test will result in a decrease or loss of sensitivity to detect the resistant viruses due to repopulation of wild-type virus.

Immunological failure had previously been used as criteria for treatment failure and is still used in various resource-limited settings. Recent studies however, have clearly demonstrated that defined criteria of $\mathrm{CD} 4+\mathrm{T}$ cell decline have a low sensitivity and specificity to detect treatment failure [46-48, 60]. More importantly, patients usually accumulate resistance mutations when immunological failure occurs. In addition, some patients have a decrease or delayed increase of CD4+ T-cell count despite undetectable VL that may lead to a misdiagnosis of treatment failure and result in unnecessary ART switching. Clinical failure is the most delayed endpoint to diagnose treatment failure and should not be used in place of VL and CD4+ T-cell count. Patients usually have virological and immunological failure for months or even years before the clinical failure occurs. IRIS needs to be excluded before a diagnosis of clinical failure. Once again, it is clear that early detection of treatment failure, particularly using monitoring of plasma VL, can preserve the future options for ART [61].

\section{Antiretroviral therapy for patients with treatment failure}

Recent studies have demonstrated that a high proportion of treatment-experienced patients can achieve a VL level of $<50$ copies $/ \mathrm{mL}$ when at least two active antiretroviral agents are added [43, 62]. There currently are more new classes and more potent ARVs in the former classes available. Therefore, the ultimate aim to treat treatment-experienced patients is to re-achieve VL suppression to $<50$ copies/ $\mathrm{mL}$ [43]. When this goal is not achievable, stability of CD4+ Tcell count and clinical status may be maintained for a period of time with a selection of a suitable ART regimen, based-on resistance test guidance and probably with a recycling of 3TC to minimize HIV-1 viral fitness.

A careful review of the previous ARV history, all previous HIV-1 genotype resistance test results, potential drug-drug interactions, relevant comorbidities, ARV availability, and a patient's adherence is very crucial to properly plan for the next ART 
regimen. For selecting subsequent therapy in patients with treatment failure, ideally, a new regimen should include three active ARVs. If this is not possible, at least two active drugs are required. To prevent rapid development of HIV drug resistance, using or adding only one active drug in the new regimen is not recommended. After commencing the new regimen, treatment adherence, drug interaction, and tolerability should be assessed and plasma VL should be tested at least three months later.

Almost all Thai patients started treatment with NNRTI-based ART, thus failing an NNRTI-based regimen is much more common than failing a PIbased regimen. In patients who failed an initial NNRTI-based regimen with 3TC included, NNRTI resistance mutations and M184V/I (3TC resistance) are commonly observed. Thymidine analog-associated mutations (TAMs) including M41L, D67N, K70R, L210W, T215Y/F, and K219Q/E, can be found in more than one-third of patients. K65R and Q151M are observed in patients with late detection of virological failure when plasma VL was more than $4 \log _{10}$ (Copies/mL) [59, 63, 64]. There is no controlled study to address appropriate second-line treatment options in patients failing NNRTI-based regimens. Therefore, the following recommendation is solely based on expert opinion. In a setting like Thailand where new ARV classes such as integrase inhibitors and CCR-5 receptor inhibitors are not affordable, a boosted-PI in combination with two active NRTIs guided by the results of resistance genotype test [65] should be used as the second ART regimen. In patients who have only one active NRTI available, 3TC may be considered for inclusion in the second regimen together with boosted lopinavir plus the active NRTI. For late failure patients who have no active NRTI available at all, it is not known whether a monoboosted PI will result in durable viral suppression like with a boosted PI in combination with two recycled NRTIs. Recent clinical trials showed no benefit of double-boosted PIs over single-boosted PIs [36, 60,
66-69]. Expert consultation or referral to a secondline randomized trial is therefore advised. In patients failing an initial PI-based regimen, NRTI resistance mutations are commonly observed. PI resistanceassociated mutations are rare in boosted-PI regimens. However, PI resistance-associated mutations are accumulated in patients with late detection of virological failure. Choosing a new PI in the new regimen is based on the number and patterns of PI resistance mutations [70]. An active PI, boosted with ritonavir, should be used as a second regimen combined with the two other active drugs, either NRTI or NNRTI, as indicated by the genotype resistance test results. Table 7 summarizes the options for the second-line ART regimens.

In patients with multiple drug class treatment failures, multiple drug resistance to NRTIs, NNRTIs and PIs are common. The ideal next regimen is to use at least two new active ARVs, such as darunavir (second generation PI), etravirine (second generation NNRTI), and/or raltegravir [71]. Strategies to increase access to new ARVs in Thailand in the near future are being considered in the National AIDS Program. In cases where there is no active drug option available, expert consultation or referral to an appropriate clinical trial is advised. While waiting for new drugs, a holding regimen consisting of $3 \mathrm{TC}$ and other NRTIs may be considered.

\section{Conclusion}

The panel has recommended a number of major changes from the Thai 2008 guidelines. Those changes include commencement of ART earlier at CD4+ $\mathrm{T}$ cell count $<350$ cells $/ \mathrm{mm}^{3}$, ART initiation is recommended regardless of CD4+ $\mathrm{T}$ cell count if patients have an indication to treat their HBV coinfection, preferred first regimen uses 3TC with AZT or TDF, not d4T as the NRTI-backbone, and efavirenz is now considered a preferred NNRTI, along with nevirapine.

Table 7. Recommended second-line ART regimens for patients with treatment failure.

\begin{tabular}{ll}
\hline First regimens & \multicolumn{1}{c}{ Recommended second regimens } \\
\hline 2 NRTIs + NNRTI & Boosted PI + 2 active NRTIs indicated by genotype testing \\
2 NRTIs + boosted PI & 1) active boosted PI + 2 active NRTIs indicated by genotype testing \\
& 2) active boosted PI + 1 NNRTI \pm 1 NRTI indicated by genotype testing \\
& 3) NNRTI + 2 active NRTIs indicated by genotype testing \\
& This option can be used only when there are 2 active NRTIs and the patient \\
& has never been exposed to NNRTI, or NRTI monotherapy or duotherapy.
\end{tabular}




\section{Acknowledgements}

The Adults and Adolescents Committee of the Thai National HIV Guidelines Working Group acknowledges the following participants in formulating these guidelines:

Praphan Phanuphak, Kiat Ruxrungtham, Narin Hiransuthikul, Sanchai Chasombat, Somnuek Sungkanuparph, Sasisopin Kiertiburanakul, Wasun Chantratita, Chitalada Uthaipiboon, Achara Teeraratkul, Rangsima Lolekha, Ploenchan Chetchotisakd, Piroon Mootsikapun, Siriluck Anunnatsiri, Sombat Thanprasertsuk, Kovit Yongvanitjit, Chanthanna Vitavasiri, Noppadon Paibulsin, Isara Chiawiriyabunya, Somsit Tansuphasawadikul, Wisit Prasithsirikul, Boonchai Kowadisaiburana, Weerawat Manosuthi, Chureerat Bowonwatanwong, Pacharee Kantipong, Winai Ratanasuwan, Thanomsak Anekthananon, Wichai Techasathit, Surapol Suwanagool, Manoon Leechawengwong, Warangkana Munsakul, Anchalee Avihingsanon, Yuthichai Kasetjaroen, Supatcharee Meekrut, Akechittra Sukkul, Sorakij Bhakeecheep, Narisa Mantharngkul, Woraphot Tantisiriwat, Aree Kumpitak, Verapun Ngammee, Nattaporn Kongsakunkrai, Supreecha Sirieam.

\section{References}

1. Palella FJ, Delaney KM, Moorman AC, Loveless MO, Fuhrer J, Satten GA, et al. Declining morbidity and mortality among patients with advanced human immunodeficiency virus infection. HIV Outpatient Study Investigators. N Engl J Med. 1998; 338:853-60.

2. Egger M, Hirschel B, Francioli P, Sudre P, Wirz M, Flepp $\mathrm{M}$, et al. Impact of new antiretroviral combination therapies in HIV infected patients in Switzerland: prospective multicentre study. Swiss HIV Cohort Study. BMJ. 1997; 315:1194-9.

3. Sungkanuparph S, Kiertiburanakul S, Manosuthi W, Kiatatchasai W, Vibhagool A. Initiation of highly active antiretroviral therapy in advanced AIDS with CD4 $<50$ cells $/ \mathrm{mm}^{3}$ in a resource-limited setting: efficacy and tolerability. Int J STD AIDS. 2005; 16:243-6.

4. Kiertiburanakul S, Sungkanuparph S, Rattanasiri S, Manosuthi W, Vibhagool A, Thakkinstian A. Virological and immunological responses of efavirenzbased HAART regimen initiated in HIV-infected patients at $\mathrm{CD} 4<100$ versus $\mathrm{CD} 4>$ or $=100$ cells $/ \mathrm{mm}^{3}$. J Med Assoc Thai. 2006; 89:1381-7.

5. Manosuthi W, Chottanapand S, Thongyen S, Chaovavanich A, Sungkanuparph S. Survival rate and risk factors of mortality among HIV/tuberculosiscoinfected patients with and without antiretroviral therapy. J Acquir Immune Defic Syndr. 2006; 43:42-6.

6. Jongwutiwes U, Kiertiburanakul S, Sungkanuparph S. Impact of antiretroviral therapy on the relapse of cryptococcosis and survival of HIV-infected patients with cryptococcal infection. Curr HIV Res. 2007; 5: 355-60.

7. Anekthananon $\mathrm{T}$, Ratanasuwan $\mathrm{W}$, Techasathit $\mathrm{W}$, Sonjai A, Suwanagool S. Safety and efficacy of a simplified fixed-dose combination of stavudine, lamivudine and nevirapine (GPO-VIR) for the treatment of advanced HIV-infected patients: a 24-week study. J Med Assoc Thai. 2004; 87:760-7.

8. Tin EE, Bowonwatanuwong C, Desakorn V, Wilairatana P, Krudsood S, Pitisuttithum P. The efficacy and adverse effects of GPO-VIR (stavudine+lamivudine+ nevirapine) in treatment-naive adult HIV patients. Southeast Asian J Trop Med Public Health. 2005; 36: 362-9.

9. Chasombat $\mathrm{S}$, Lertpiriyasuwat $\mathrm{C}$, Thanprasertsuk $\mathrm{S}$, Suebsaeng L, Lo YR. The National Access to Antiretroviral Program for PHA (NAPHA) in Thailand. Southeast Asian J Trop Med Public Health. 2006; 37 : 704-15.

10. Sungkanuparph $\mathrm{S}$, Anekthananon T, Hiransuthikul N, Bowonwatanuwong C, Supparatpinyo K, Mootsikapun P, et al; Thai AIDS Society. Guidelines for antiretroviral therapy in HIV-1 infected adults and adolescents: the recommendations of the Thai AIDS Society (TAS) 2008. J Med Assoc Thai. 2008; 1:925-35.

11. Panel on Antiretroviral Guidelines for Adults and Adolescents. Guidelines for the use of antiretroviral agents in HIV-1-infected adults and adolescents. Department of Health and Human Services. December 1,2009; 1-161. Available at http://www.aidsinfo.nih.gov/ ContentFiles/AdultandAdolescentGL.pdf. Accessed 11 April 2010.

12. World Health Organization. Rapid advice: antiretroviral therapy for HIV infection in adults and adolescents November 2009; 1-24. Available at http://www.who.int/ $\mathrm{HIV} /$ pub/arv/rapid_advice_art.pdf. Accessed 11 April 2010.

13. Manosuthi W, Kiertiburanakul S, Phoorisri T, Sungkanuparph S. Immune reconstitution inflammatory syndrome of tuberculosis among HIVinfected patients receiving antituberculous and antiretroviral therapy. J Infect. 2006; 53:357-63.

14. Sungkanuparph S, Jongwutiwes U, Kiertiburanakul S. Timing of cryptococcal immune reconstitution 
inflammatory syndrome after antiretroviral therapy in patients with AIDS and cryptococcal meningitis. J Acquir Immune Defic Syndr. 2007; 45:595-6.

15. Sungkanuparph S, Vibhagool A, Manosuthi W, Kiertiburanakul S, Atamasirikul K, Aumkhyan A, Thakkinstian A. Prevalence of hepatitis B virus and hepatitis $\mathrm{C}$ virus co-infection with human immunodeficiency virus in Thai patients: a tertiarycare-based study. J Med Assoc Thai. 2004; 87: 1349-54.

16. Sungkanuparph S, Wongprasit P, Manosuthi W, Atamasirikul K. Compliance with hepatitis B and hepatitis $\mathrm{C}$ virus infection screening among HIV-1 infected patients in a resource-limited setting. Southeast Asian J Trop Med Public Health. 2008; 39 : 863-6.

17. Phillips AN, Leen C, Wilson A, Anderson J, Dunn D, Schwenk A, et al. UK Collaborative HIV Cohort (CHIC) Study. Risk of extensive virological failure to the three original antiretroviral drug classes over long-term follow-up from the start of therapy in patients with HIV infection: an observational cohort study. Lancet. 2007; 370:1923-8.

18. de Beaudrap P, Etard JF, Guèye FN, Guèye M, Landman R, Girard PM, et al; ANRS 1215/1290 Study Group. Long-term efficacy and tolerance of efavirenz- and nevirapine-containing regimens in adult HIV type 1 Senegalese patients. AIDS Res Hum Retroviruses. 2008; 24:753-60.

19. Egger S, Petoumenos K, Kamarulzaman A, Hoy J, Sungkanuparph S, Chuah J, et al; Asia Pacific HIV Observational Database (APHOD). Long-term patterns in CD4 response are determined by an interaction between baseline CD4 cell count, viral load, and time: The Asia Pacific HIV Observational Database (APHOD). J Acquir Immune Defic Syndr. 2009; 50: 513-20.

20. Sungkanuparph S, Chakriyanuyok T, Butthum B. Antiretroviral therapy in AIDS patients with CMV disease: impact on the survival and long-term treatment outcome. J Infect. 2008; 56:40-3.

21. Ananworanich J, Gayet-Ageron A, Ruxrungtham K, Chetchotisakd P, Prasithsirikul W, Kiertiburanakul S, et al; Staccato Thailand Study Group. Long-term efficacy and safety of first-line therapy with once-daily saquinavir/ritonavir. Antivir Ther. 2008; 13:375-80.

22. Duncombe C, Kerr SJ, Ruxrungtham K, Dore GJ, Law MG, Emery S, et al. HIV disease progression in a patient cohort treated via a clinical research network in a resource limited setting. AIDS. 2005; 19:169-78.
23. Lohse N, Hansen AB, Pedersen G, Kronborg G, Gerstoft J, Srrensen HT, et al. Survival of persons with and without HIV infection in Denmark, 1995-2005. Ann Intern Med. 2007; 146:87-95.

24. CDC. 1993 revised classification system for HIV infection and expanded surveillance case definition for AIDS among adolescents and adults. MMWR Recomm Rep. 1992; 41(RR-17):1-19.

25. Supparatpinyo K, Chiewchanvit S, Hirunsri P, Uthammachai C, Nelson KE, Sirisanthana T. Penicillium marneffei infection in patients infected with human immunodeficiency virus. Clin Infect Dis. 1992; 14: $871-4$.

26. Zolopa A, Andersen J, Powderly W, Sanchez A, Sanne I, Suckow C, et al. Early antiretroviral therapy reduces AIDS progression/death in individuals with acute opportunistic infections: a multicenter randomized strategy trial. PLoS One. 2009; 4:e5575.

27. Sterne JA, May M, Costagliola D, de WolfF, Phillips A, Harris R, et al. Timing of initiation of antiretroviral therapy in AIDS-free HIV-1-infected patients: a collaborative analysis of $18 \mathrm{HIV}$ cohort studies. Lancet. 2009; 373:1352-63.

28. Baker JV, Peng G, Rapkin J, Abrams DI, Silverberg MJ, MacArthur RD, et al. CD4+ count and risk of non-AIDS diseases following initial treatment for HIV infection. AIDS. 2008; 22:841-8.

29. Emery S, Neuhaus JA, Phillips AN, Babiker A, Cohen CJ, Gatell JM, et al. Major clinical outcomes in antiretroviral therapy (ART)-naive participants and in those not receiving ART at baseline in the SMART study. J Infect Dis. 2008; 197:1133-44.

30. Severe P, Pape J, Fitzgerald DW. A randomized clinical trial of early versus standard antiretroviral therapy for HIV-infected patients with a CD4 T cell count of 200350 cells $/ \mathrm{mL}$ (CIPRAHT001). Presented at the 46th ICAAC, San Francisco, September, 2009 (Abstract H-1230c).

31. Chaiwarith R, Salee P, Kotarathitithum W, Sirisanthana T, Supparatpinyo K. Long-term CD4 cell count recovery among Thai naive HIV-infected patients initiating HAART at low CD4 cell count. Curr HIV Res. 2009; 7: 340-5.

32. Manosuthi W, Sungkanuparph S, Vibhagool A, Rattanasiri S, Thakkinstian A. Nevirapine- versus efavirenz-based highly active antiretroviral therapy regimens in antiretroviral-naive patients with advanced HIV infection. HIV Med. 2004; 5:105-9.

33. Chuapai Y, Kiertiburanakul S, Malathum K, Sungkanuparph S. Lipodystrophy and dyslipidemia in 
human immunodeficiency virus-infected Thai patients receiving antiretroviral therapy. J Med Assoc Thai. 2007; 90:452-8.

34. Puttawong S, Prasithsirikul W, Vadcharavivad S. Prevalence of lipodystrophy in Thai-HIV infected patients. J Med Assoc Thai. 2004; 87:605-11.

35. Manosuthi W, Sungkanuparph S, Thakkinstian A, Vibhagool A, Kiertiburanakul S, Rattanasiri S, et al. Efavirenz levels and 24-week efficacy in HIV-infected patients with tuberculosis receiving highly active antiretroviral therapy and rifampicin. AIDS. 2005; 19 : 1481-6.

36. Manosuthi W, Sungkanuparph S, Thakkinstian A, Rattanasiri S, Chaovavanich A, Prasithsirikul W, Prasithsirikul W, Inthong Y, Phoorisri T, Sungkanuparph S. Plasma nevirapine levels and 24-week efficacy in HIV-infected patients receiving nevirapine-based highly active antiretroviral therapy with or without rifampicin. Clin Infect Dis. 2006; 43: 253-5.

37. Abdool Karim SS, Naidoo K, Grobler A, Padayatchi N, Baxter C, Gray A, et al. Timing of initiation of antiretroviral drugs during tuberculosis therapy. N Engl J Med. 2010; 362:697-706.

38. Sungkanuparph S, Manosuthi W, Kiertiburanakul S, Vibhagool A. Initiation of antiretroviral therapy in advanced AIDS with active tuberculosis: clinical experiences from Thailand. J Infect. 2006; 52:188-94.

39. Manosuthi W, Kiertiburanakul S, Sungkanuparph S, Ruxrungtham K, Vibhagool A, Rattanasiri S, Thakkinstian A. Efavirenz $600 \mathrm{mg}$ /day versus efavirenz $800 \mathrm{mg}$ /day in HIV-infected patients with tuberculosis receiving rifampicin: 48 weeks results. AIDS. 2006; 20 : 131-2.

40. Manosuthi W, Sungkanuparph S, Tantanathip P, Lueangniyomkul A, Mankatitham W, Prasithsirskul W, et al; N2R Study Team. A randomized trial comparing plasma drug concentrations and efficacies between 2 nonnucleoside reverse-transcriptase inhibitor-based regimens in HIV-infected patients receiving rifampicin: the N2R Study. Clin Infect Dis. 2009; 48:1752-9.

41. Manosuthi W, Ruxrungtham K, Likanonsakul S, Prasithsirikul W, Inthong Y, Phoorisri T, et al. Nevirapine levels after discontinuation of rifampicin therapy and 60-week efficacy of nevirapine-based antiretroviral therapy in HIV-infected patients with tuberculosis. Clin Infect Dis. 2007; 44:141-4.

42. Avihingsanon A, Manosuthi W, Kantipong P, Chuchotaworn C, Moolphate S, Yamada N, et al. Pharmacokinetics and 48 weeks efficacy of nevirapine:
$400 \mathrm{mg}$ versus $600 \mathrm{mg}$ per day in HIV-Tuberculosis coinfection receiving rifampicin. Antivir Ther. 2008; 13: 529-36.

43. Hammer SM, Saag MS, Schechter M, Montaner JSG, Schooley RT, Jacobsen DM, et al. Antiretroviral treatment of adult HIV infection: 2008 recommendations of the International AIDS Society-USA Panel. JAMA. 2008; 300:555-70.

44. Raboud JM, Rae S, Hogg RS, Yip B, Sherlock CH, Harrigan PR, et al. Suppression of plasma viral load below the detection limit of a human immunodeficiency virus kit is associated with longer virologic response than suppression below the limit of quantitation. J Infect Dis. 1999;180:1347-50.

45. Kaufmann GR, Perrin L, Pantaleo G, Opravil M, Furrer $\mathrm{H}$, Telenti A, et al. CD4 T-lymphocyte recovery in individuals with advanced HIV-1 infection receiving potent antiretroviral therapy for 4 years: the Swiss HIV Cohort Study. Arch Intern Med. 2003; 163:2187-95.

46. Mee P, Fielding KL, Charalambous S, Churchyard GL, Grant AD. Evaluation of the WHO criteria for antiretroviral treatment failure among adults in South Africa. AIDS. 2008; 22:1971-7.

47. Badri M, Lawn SD, Wood R. Utility of CD4 cell counts for early prediction of virological failure during antiretroviral therapy in a resource-limited setting. BMC Infect Dis. 2008; 8:89.

48. Kantor R, Diero L, Delong A, Kamle L, Muyonga S, Mambo F, et al. Misclassification of first-line $\underline{\text { antiretroviral treatment failure based on immunological }}$ monitoring of HIV infection in resource-limited settings. Clin Infect Dis. 2009; 49:454-62.

49. Nuesch R, Srasuebkul P, Ananworanich J, Ruxrungtham K, Phanuphak P, Duncomb C. HIV-NAT Study Team. Monitoring the toxicity of antiretroviral therapy in resource limited settings: a prospective clinical trial cohort in Thailand. J Antimicrob Chemother. 2006; 58:637-44.

50. Sungkanuparph S, Kiertiburanakul S, Apisarnthanarak A, Malathum K, Sathapatayavongs B. HIV-1 genotype after interruption of non-nucleoside reverse transcriptase inhibitor-based antiretroviral therapy and virological response after resumption of the same regimen. Int J STD AIDS. 2007; 18:832-4.

51. Homsanit M, Nelson KE, Sonjai A, Anekthananon T, Suwanagool S, Cofrancesco J Jr. Body shape and metabolic abnormalities in Thai HIV-infected patients. AIDS Res Hum Retroviruses. 2007; 23:1314-21.

52. Hiransuthikul N, Hiransuthikul P, Kanasook Y. Lipid profiles of Thai adult HIV-infected patients receiving 
protease inhibitors. Southeast Asian J Trop Med Public Health. 2007; 38:69-77.

53. Ananworanich J, Nuesch R, Côté HC, Kerr SJ, Hill A, Jupimai T, Laopraynak N, et al. Changes in metabolic toxicity after switching from stavudine/didanosine to tenofovir/lamivudine-a Staccato trial substudy. J Antimicrob Chemother. 2008; 61:1340-3.

54. Kerr SJ, Duncombe C, Avihingsanon A, Ananworanich J, Boyd M, Sopa B, et al. Dyslipidemia in an Asian population after treatment for two years with protease inhibitor-containing regimens. J Int Assoc Physicians AIDS Care (Chic Ill). 2007; 6:36-46.

55. Sungkanuparph S, Vibhagool A, Mootsikapun P, Chetchotisakd P, Tansuphaswaswadikul S, Bowonwatanuwong C. Opportunistic infections after the initiation of highly active antiretroviral therapy in advanced AIDS patients in an area with a high prevalence of tuberculosis. AIDS. 2003; 17:2129-31.

56. Manosuthi W, Chaovavanich A, Tansuphaswadikul S, Prasithsirikul W, Inthong Y, Chottanapund S, et al. Incidence and risk factors of major opportunistic infections after initiation of antiretroviral therapy among advanced HIV-infected patients in a resourcelimited setting. J Infect. 2007; 55:464-9.

57. Sungkanuparph S, Filler SG, Chetchotisakd P, Pappas PG, Nolen TL, Manosuthi W, et al. Cryptococcal immune reconstitution inflammatory syndrome after antiretroviral therapy in AIDS patients with cryptococcal meningitis: a prospective multicenter study. Clin Infect Dis. 2009; 49:931-4.

58. Müller M, Wandel S, Colebunders R, Attia S, Furrer H, Egger M; IeDEA Southern and Central Africa. Immune reconstitution inflammatory syndrome in patients starting antiretroviral therapy for HIV infection: a systematic review and meta-analysis. Lancet Infect Dis. 2010; 10:251-61.

59. Marais S, Wilkinson RJ, Pepper DJ, Meintjes G. Management of patients with the immune reconstitution inflammatory syndrome. Curr HIV/AIDS Rep. 2009; 6:162-71.

60. Chaiwarith R, Wachirakaphan C, Kotarathititum W, Praparatanaphan J, Sirisanthana T, Supparatpinyo K. Sensitivity and specificity of using CD4+ measurement and clinical evaluation to determine antiretroviral treatment failure in Thailand. Int J Infect Dis. 2007; 11: 413-6.

61. Sungkanuparph S, Manosuthi W, Kiertiburanakul S, Piyavong B, Chumpathat N, Chantratita W. Options for a second-line antiretroviral regimen for HIV type 1 -infected patients whose initial regimen of a fixed- dose combination of Stavudine, Lamivudine, and Nevirapine fails. Clin Infect Dis. 2007; 44:447-52.

62. Nelson M, Arasteh K, Clotet B, Cooper DA, Henry K, Katlama C, et al. Durable efficacy of enfuvirtide over 48 weeks in heavily treatment-experienced HIV-1infected patients in the T-20 versus optimized background regimen only 1 and 2 clinical trials. J Acquir Immune Defic Syndr. 2005; 40:404-12.

63. Chetchotisakd P, Anunnatsiri S, Kiertiburanakul S, Sutthent R, Anekthananon T, Bowonwatanuwong C, et al. High rate multiple drug resistances in HIV-infected patients failing nonnucleoside reverse transcriptase inhibitor regimens in Thailand, where subtype $\mathrm{A} / \mathrm{E}$ is predominant. J Int Assoc Physicians AIDS Care (Chic Ill). 2006; 5:152-6.

64. Sungkanuparph S, Manosuthi W, Kiertiburanakul S, Saekang N, Pairoj W, Chantratita W. Prevalence and risk factors for developing K65R mutations among HIV-1 infected patients who fail an initial regimen of fixed-dose combination of stavudine, lamivudine, and nevirapine. J Clin Virol. 2008; 41:310-3.

65. Palella FJ Jr, Armon C, Buchacz K, Cole SR, Chmiel JS, Novak RM, et al; HOPS (HIV Outpatient Study) Investigators. The association of HIV susceptibility testing with survival among HIV-infected patients receiving antiretroviral therapy: a cohort study. Ann Intern Med. 2009; 151:73-84.

66. Walmsley SL, Katlama C, Lazzarin A, Arestéh K, Pierone G, Blick G, et al. Pharmacokinetics, safety, and efficacy of tipranavir boosted with ritonavir alone or in combination with other boosted protease inhibitors as part of optimized combination antiretroviral therapy in highly treatment-experienced patients (BI Study 1182.51). J Acquir Immune Defic Syndr. 2008; 47 : 429-40.

67. Chetchotisakd P, Anunnatsiri S, Mootsikapun P, Kiertiburanakul S, Anekthananon T, Bowonwatanuwong C. Study Team. Efficacy and tolerability of a double boosted protease inhibitor (lopinavir +saquinavir/ritonavir) regimen in HIV-infected patients who failed treatment with nonnucleoside reverse transcriptase inhibitors. HIV Med. 2007; 8: 529-35.

68. van der Lugt J, Autar RS, Ubolyam S, Garcia EF, Sankote J, Avihingson A, et al. HIV-NAT 019 Study Team. Pharmacokinetics and short-term efficacy of a doubleboosted protease inhibitor regimen in treatment-naive HIV-1-infected adults. J Antimicrob Chemother. 2008; 61:1145-53.

69. Manosuthi W, Sungkanuparph S, Ruxrungtham K, 
Prasithsirikul W, Athichathanabadi C, Tantisiriwat W, et al. Plasma levels, safety, and 60-week efficacy of a once-daily double-boosted protease inhibitor regimen of atazanavir, saquinavir, and ritonavir. J Acquir Immune Defic Syndr. 2008; 47:127-9.

70. Johnson VA, Brun-Vezinet F, Clotet B, Gunthard HF, Kuritzkes DR, Pillay D, et al. Update of the drug resistance mutations in HIV-1: December 2009. Top
HIV Med. 2009; 17:138-45.

71. Yazdanpanah Y, Fagard C, Descamps D, Taburet AM, Colin C, Roquebert B, et al. High rate of virologic suppression with raltegravir plus etravirine and darunavir/ritonavir among treatment-experienced patients infected with multidrug-resistant HIV: results of the ANRS 139 TRIO Trial. Clin Infect Dis. 2009; 49: 1441-9. 